\title{
EFFECT OF DIETARY CONSUMPTION PATTERN, NUTRITION STATUS, AND HEMOGLOBIN LEVEL ON ACADEMIC ACHIEVEMENT AMONG HIGH SCHOOL STUDENTS IN KUPANG, EAST NUSA TENGGARA
}

\author{
Frida S Pay'), Intje Picauly²), Sabina Gero'3) \\ 1) School of Health Science, Maranatha, Kupang \\ 2) Masters Program in Public Health, Universitas Nusa Cendana \\ 3) School of Health Polytechnics, Ministry of Health, Kupang
}

\begin{abstract}
Background: A healthy diet has been reported to be associated with physical development, cognition and academic performance, and personality during adolescence. This study aimed to estimate the effects of dietary consumption pattern, nutrition status, and hemoglobin level on academic achievement among high school students in Kupang, East Nusa Tenggara.

Subjects and Method: This was a cross-sectional study conducted at Senior High School, Kupang district, East Nusa Tenggara, Indonesia, from December 2014 to March 2015. A total sample of 206 students was selected for this study by simple random sampling. The dependent variable was academic achievement. The independent variables were type of food consumed, food consumed rate, protein intake rate, nutritional status, and hemoglobin level. The data were collected by interview. The data were analyzed by a multiple linear regression.

Results: Academic achievement increased with hemoglobin level $(b=1.27 ; 95 \%$ $\mathrm{CI}=0.45$ to $2.08 ; \mathrm{p}=0.02)$, energy $(\mathrm{b}=0.01 ; 95 \% \mathrm{CI}=0.003$ to $0.01 ; \mathrm{p}<0.001)$, protein intake $(\mathrm{b}=0.09 ; 95 \% \mathrm{CI}=0.02$ to $0.15 ; \mathrm{p}=0.007)$, nutritional status $(\mathrm{b}=$ $0.47 ; 95 \% \mathrm{CI}=0.15$ to $0.78 ; \mathrm{p}=0.004)$.
\end{abstract}

Conclusion: Academic achievement increases with hemoglobin level, energy, protein intake, and nutritional status.

Keywords: academic achievement, hemoglobin level, energy, protein intake, and nutritional status.

\section{Correspondence:}

Frida S Pay. District Health Office, Kupang, East Nusa Tenggara, Indonesia.

Email: rafpun012@gmail.com. Mobile: 081338353340.

The 4th International Conference on Public Health 